\title{
Orthogonal Array Approach for Optimization of Carrageenase Production by Solid State Fermentation of Pseudomonas aeruginosa ZSL-2
}

Ziayoddin $\mathbf{M}^{1}$, Manohar Shinde ${ }^{2}$ and Junna Lalitha ${ }^{1 *}$

${ }^{1}$ Department of Biochemistry, Gulbarga University, Gulbarga-585106, Karnataka, India

${ }^{2}$ Department of Studies and Research in Biochemistry, Tumkur University, Tumkur-572103, Karnataka, India

\begin{abstract}
The optimization of solid-substrate medium and fermentation conditions for the production of enzyme carrageenase by a Pseudomonas aeruginosa ZSL-2 was achieved for the first time by employing an orthogonal array testing strategy (OATS). Of the four different substrates tested, wheat bran showed maximum production of carrageenase enzyme. The factors that influence the solid-substrate fermentation (SSF) conditions such as, moisture content, moistening agent, temperature, $\mathrm{pH}$, inoculum size, additional carbon source and the fermentation period for the production of enzyme were studied by one-factor at a time and also by $\mathrm{L} 9\left(3^{4}\right)$ an orthogonal array method. The maximal production of k-carragenase $(7.44 \mathrm{U} / \mathrm{g})$ dry bacterial bran was achieved at moisture level $1: 2.5\left(\mathrm{w} / \mathrm{v}\right.$; wheat bran to moisture level), moistening agent IV, inoculum size $(10 \%)$, temperature $37^{\circ} \mathrm{C}$ and $48 \mathrm{~h}$ of fermentation. The effects of various parameters like medium, inoculum size, temperature, moistening agent, moisture level, incubation period, and supplementation of other carbon sources on the production of carrageenase by SSF using OATS is investigated and the results are presented and discussed.
\end{abstract}

Keywords: Carrageenase; Pseudomonas aeruginosa ZSL-2; Solid state fermentation (SSF); Orthogonal array testing strategy (OATS)

\section{Introduction}

The submerged fermentation $(\mathrm{SmF})$ has been used traditionally for the production of industrially important enzymes as it allows greater control of environmental factors such as, temperature, $\mathrm{pH}$, oxygen supply, ease of handling and study the rheology of the culture medium but, it demands expensive instrument, medium and the cumbersome downstream purification of product due to very high volume. However, solid-substrate fermentation (SSF) is viewed as an interesting alternative over $\mathrm{SmF}$ as the downstream process is less expensive [1-4]. SSF is preferred to SmF for it shows high production of better quality product, simple and environmental friendly process, low capital investment, low levels of repression [5] and most importantly it makes use of cheap and inexpensive agricultural wastes or by-products for the production of high value products [4,6-8].

Bacterial systems are being increasingly investigated for the production of enzymes and metabolites by SSF, as it offers advantages over SmF; including economy, simplicity of the space needed for fermentation media; easier scale up of processes; lesser volume of solvent needed for product recovery; superior yields; absence of foam build-up; and easier control of contamination due to the low moisture level in the system [8-13]. SSF systems appear to be simulating the natural habitats of microbe, thus this system may prove to be more efficient for the production of certain enzymes and metabolites [11-14]. SSF process are usually simpler, that uses inexpensive raw materials like by-products of food-processing and agricultural industry as substrates, such as, gram bran, wheat bran, rice bran, banana waste, sugarcane bagasse, defatted soybean cake, groundnut cake etc, for the production of various enzymes by different microorganisms [15-17].

Carrageenans are the main cell wall components of various marine red algae (Rhodophyceae) and are widely used as thickening and gelling agents in structural and functional applications of foods and generally regarded as safe (GRAS) by the Food and Drug Administration in the United States. Marine microorganisms that hydrolyze carrageenans have been of enormous interest for their potential applications in food, cosmetic and pharmaceutical industry. $\kappa$-Carrageenase (EC
3.2.1.83), hydrolyzes $\beta-1,4$ linkages in $\kappa$ - carrageenan, is a useful tool for the isolation of protoplast from red algae and also finds significant application in the structural analysis of the cell wall carrageenans [18]. The production of carrageenases by submerged fermentation using several bacterial genera including Pseudomonas carrageenovora [19,20], Cytophaga [21,22], Alteromonas carrageenovora [23,24], Vibrio sp. [25] and Zobellia galactanovorans [22,26] has been reported. Owing to the potential biotechnological applications in the field of seaweed biotechnology, the improvement in the bioprocess technology for the large scale production of $\kappa$-carrageenases gained current interest. There is an urgent need to develop a feasible bioprocess technology for the large scale production of this enzyme system. Therefore, the best and economically viable strategy for the large scale production of $\kappa$-carrageenases is to increase its productivity by optimization of the medium and fermentation conditions prior to its scale up as, the optimization of media composition with a balanced proportion of various nutrients is regarded as an essential corollary for the maximum growth of biomass for high quantity and quality product yield. Extensive efforts are still needed to enhance the performance of SSF bioprocess by optimizing the nutritional requirement and environmental conditions to increase the effectiveness factor and yield coefficient. The optimization of fermentation medium and environmental factors by one factor at a time involves change of one of independent variables like moisture, temperature, $\mathrm{pH}$ etc., while fixing the others at certain levels. The single dimensional search is laborious and time-consuming

*Corresponding author: Junna Lalitha, Department of Biochemistry, Gulbarga University, Gulbarga-585106, Karnatak, India, Fax: +91-8472-245927; E-mail jlshinde@rediffmail.com

Received June 30, 2012; Accepted September 10, 2012; Published September 12, 2012

Citation: Ziayoddin M, Shinde M, Lalitha J (2012) Orthogonal Array Approach for Optimization of Carrageenase Production by Solid State Fermentation of Pseudomonas aeruginosa ZSL-2. J Microb Biochem Technol 4: 096-095. doi:10.4172/1948-5948.1000078

Copyright: @ 2012 Ziayoddin M, et al. This is an open-access article distributed under the terms of the Creative Commons Attribution License, which permits unrestricted use, distribution, and reproduction in any medium, provided the original author and source are credited 
especially, when one needs to optimize large number of variables [27]. Therefore decisive statistical methods are preferred for bioprocess optimization as, they reduce the total number of experiments that help to pinpoint unerringly the optimal levels of combinations of various nutrients, environmental conditions and the combination there of for better biomass production and enzyme yield by SSF.

In the present investigation we have made an attempt to explore the potentials of marine carrageenolytic bacterium, Pseudomonas aeruginosa ZSL-2 for the maximal production of carrageenase by optimization of media and culture conditions by SSF. The fermentation conditions were optimized using a combination of one factor at a time and statistics based orthogonal array testing strategy (OATS) to test the pair-wise interactions among the culture parameters.

\section{Methods}

\section{Microorganism and culture media}

An agarolytic Pseudomonas aeruginosa ZSL-2 isolated from marine environment was inoculated in minimal mineral salts (MMS) medium composed of (g/l) $\mathrm{K}_{2} \mathrm{HPO}_{4}(0.38), \mathrm{MgSO}_{4}(0.20), \mathrm{NaNO}_{3}(1.0), \mathrm{FeCl}_{3}$ $(0.05)$ and agar (3.0). This strain was routinely maintained and stored at $4^{\circ} \mathrm{C}$ on MMS-agar slants in the laboratory. Seed culture was prepared from $24 \mathrm{~h}$ grown culture on MMS liquid broth at $180 \mathrm{rpm}$ and $37^{\circ} \mathrm{C}$ [28]. The bacterium was also capable of utilizing carrageenan as sole source of carbon and energy. It was acclimatized to carrageenan for four months by growing in MMS media containing carrageenan $(0.3 \%)$ as the carbon source.

\section{Induced inoculum preparation}

A Pseudomonas aeruginosa ZSL-2, which was capable of utilizing agar as sole carbon source was adapted to grow on mineral-salts medium supplemented by carrageenan $(0.3 \% \mathrm{w} / \mathrm{v})$. The freshly inoculated bacterial culture was incubated on a rotary shaker shaking at $170 \mathrm{rpm}$ and $30^{\circ} \mathrm{C}$ for $24 \mathrm{~h}$. A $16-18 \mathrm{~h}$ grown bacterium, which was induced for the production of carrageenase enzyme, was used as inoculum for SSF.

\section{Enzyme production by SSF}

A $10 \mathrm{~g}$ of solid substrate (wheat bran, wheat straw, gram bran or paddy straw) was dispensed into $250 \mathrm{ml}$ Erlenmeyer flasks, the substrate was moistened by MMS medium and the flasks were sterilized by an autoclave at $121^{\circ} \mathrm{C}$ for $60 \mathrm{~min}$. The flasks were then inoculated by a freshly grown induced $P$. aeruginosa cultures $(10 \% \mathrm{v} / \mathrm{w})$, the cultures were mixed thoroughly and incubated at $37^{\circ} \mathrm{C}$ in dark for different time incubations.

\section{Enzyme extraction}

The fermented bacterial bran's at different incubation periods were extracted with $20 \mathrm{ml}$ of Tris- $\mathrm{HCl}$ buffer $\left(20 \mathrm{mM}\right.$; pH 7.5; $\left.4^{\circ} \mathrm{C}\right)$. The extracts were sieved by a $300 \Phi$ mesh, filtered by a Guchi (ceramic, 70-100 $\mu$ mesh) filter, permeate filtered by a $0.2 \mu \mathrm{m}$ membrane filter (Millipore) and was then centrifuged at $10000 \mathrm{rpm}$ for $15 \mathrm{~min}$ and $4^{\circ} \mathrm{C}$. The clear supernatant thus obtained was used as crude enzyme source for the assay of carrageenase activity.

\section{Enzyme assay}

Carrageenase assay was carried out by neocuproine reagent [29] using $\kappa$-carrageenan $(0.3 \%)$ as substrate. In brief, the $1 \mathrm{ml}$ assay mixture contained $20 \mathrm{mM}$ Tris- $\mathrm{HCl}$ buffer of $\mathrm{pH} 8,0.5 \mathrm{ml}$ of carrageenan $(0.3 \%$ in Tris- $\mathrm{HCl}$ buffer) and $50 \mu \mathrm{l}$ suitably diluted enzyme. The assay mixture was incubated for $10 \mathrm{~min}$ at $40^{\circ} \mathrm{C}$ and the reaction was arrested at 10 min by the addition of $1 \mathrm{ml}$ of alkaline copper reagent $\left(4 \% \mathrm{Na}_{2} \mathrm{CO}_{3}\right.$, $1.6 \%$ glycine and $\left.0.045 \% \mathrm{CuSO}_{4}\right)$. A $1 \mathrm{ml}$ of $5 \mathrm{mM}$ neocuproine- $\mathrm{HCl}$ reagent was added to the tube and was kept in a boiling water bath for 10 min. It was necessary to add ethanol $(50 \% \mathrm{v} / \mathrm{v})$ to the reaction mixture before measuring the absorbance. One unit of the enzyme activity was defined as the amount which liberated $1 \mu \mathrm{mol}$ galactose equivalent per minute under the assay conditions. Carrageenase production by SSF is expressed as units per gram of dry bacterial bran (U/g DBB). The results are the mean of three values obtained from three independent experiments

\section{Optimization of process parameters using one factor at a time method}

The different process parameters such as, substrate, temperature, $\mathrm{pH}$, moistening agent, moistening levels, incubation period, addition of different carbon sources that influence the production of carrageenase by SSF were optimized over a wide range. The strategy adopted for standardization of fermentation parameters was to evaluate the effect of an individual parameter and to incorporate it at standardized level before standardizing the next parameter.

\section{Effect of different moistening agents}

The MMS solutions of different compositions $(\mathrm{g} / \mathrm{l})$ were used as moistening agents; MMS I: $\mathrm{MgSO}_{4} \cdot 7 \mathrm{H}_{2} \mathrm{O}, 0.5 ; \mathrm{K}_{2} \mathrm{HPO}_{4}, 1.5 ; \mathrm{pH}$; MMS II: $\mathrm{MgSO}_{4} \cdot 7 \mathrm{H}_{2} \mathrm{O}, 0.5 ; \mathrm{K}_{2} \mathrm{HPO}_{4}, 1.5$; yeast extract, 2.0 ; peptone, 2.0; pH 8; MMS III: $\mathrm{K}_{2} \mathrm{HPO}_{4}, 0.1 ;\left(\mathrm{NH}_{4}\right)_{2} \mathrm{H}_{2} \mathrm{PO}_{4}, 1.0 ; \mathrm{MgSO}_{4} \cdot 7 \mathrm{H}_{2} \mathrm{O}$, $0.5 ; \mathrm{CaCl}_{2} \cdot 2 \mathrm{H}_{2} \mathrm{O}, 0.1 ; \mathrm{FeSO}_{4}, 0.1 ; \mathrm{MnSO}_{4} \cdot 7 \mathrm{H}_{2} \mathrm{O}, 0.1 \mathrm{pH} 8$ and MMS IV: $\mathrm{K}_{2} \mathrm{HPO}_{4}, 0.38 ; \mathrm{MgSO}_{4}, 0.20 ; \mathrm{FeCl}_{3}, 0.05 ; \mathrm{NaNO}_{3}, 1.0 ; \mathrm{pH}$ 8. Wheat bran moistened separately with four different mineral salts solutions was inoculated with bacterium. The carrageenase activity was analyzed in the extracts of fermented wheat bran's at $48 \mathrm{~h}$ incubation.

\section{Effect of moisture level}

The influence of moisture level on the enzyme titer was evaluated by varying the ratio $(\mathrm{w} / \mathrm{v})$ of wheat bran to mineral salt media from $1: 1$ to $1: 3$.

\section{Effect of temperature}

The influence of incubation temperature on production of the carrageenase was evaluated by performing SSF at different temperatures ranging from $20^{\circ} \mathrm{C}$ to $50^{\circ} \mathrm{C}$. The carrageenase activities were assayed in the crude extracts at $48 \mathrm{~h}$ of incubation.

\section{Effect of inoculum size}

The influence of inoculum size on the production of carrageenase was studied by the inoculation of freshly grown bacterium (5\% to $20 \%$, $\mathrm{v} / \mathrm{w}$ ) into conical flasks containing $10 \mathrm{~g}$ of sterilized, moistened wheat bran medium. The levels of enzyme and the assays were investigated as said earlier.

\section{Effect of fermentation period}

The effect of incubation period on the production of enzyme using SSF by $P$. aeruginosa in wheat bran (10 g, moistened with MMS) medium was investigated at different incubation periods. The crude enzyme from the fermented bran's was extracted at different incubation times and the levels of carrageenase were investigated as shown earlier.

\section{Statistical approach}

For the optimization of SSF parameters such as, medium and 
culture conditions for the maximum production of carrageenase, an orthogonal array testing strategy (OATS) was applied for testing pairwise interactions among the culture parameters. Based on the single factor experiments, the orthogonal L9 $\left(3^{4}\right)$ was used to obtain optimal conditions. This permits to determine the precise point (concentrations) in the important factors (medium, $\mathrm{pH}$, temp, moistening agent, moisture level etc) that lead to the best possible response [30,31]. The levels of the factors are listed in the Table 2. All the experiments were performed in triplicate and the data were expressed as mean $\pm \mathrm{SD}$ that was analyzed statistically by ANOVA method using the software Origin 8 .

\section{Effect of additives}

The effect of different additives was studied by co-supplementing wheat bran by glucose, galactose, sucrose, lactose, agar or carrageenan at an initial concentration of $1 \%(\mathrm{w} / \mathrm{w})$. The individual co-supplements were dissolved separately in MMS medium and were supplemented to the wheat bran. The sterilized bran was then inoculated by the bacterial culture. The control experiments were performed similarly but were devoid of any additives.

\section{Repression of carrageenase production by glucose}

The effect of glucose on carrageenase production by the bacterium in SSF conditions was studied by incorporating glucose at initial concentrations of $1 \%-5 \%,(w / w)$ into the SSF medium. This was prepared by dissolving glucose in MMS-IV medium to achieve a final concentration of glucose to wheat bran ratio between $1 \%$ and $5 \%$ (w/w), filter sterilized by a $0.22 \mu \mathrm{M}$ membrane filter (Millipore) and supplemented into sterilized wheat bran.

\section{Results and Discussion}

In light of the numerous advantages of SSF over SmF, the production of enzyme carrageenase by a $P$. aeruginosa ZSL-2 was attempted by SSF using various naturally occurring agricultural raw materials as substrates. The ideal solid substrate that is used in SSF should be particulate, water insoluble and also provide all the necessary nutrients. The solid substrate that is impregnated in water leaches its nutrients into the surrounding water; this nutrient-enriched water in turn supports the growth and the metabolic activity of the microbe. Thus, the selection of an appropriate solid substrate is critical to the efficient SSF process [1]. Of the four natural solid-substrates tested for SSF (Figure 1) wheat bran was found to support maximum production of carrageenase by the bacterium as it is compared to wheat straw (WS), gram bran (GB) and paddy straw (PS). It is evident from the figure that WB showed 5.8 units of enzyme per gram of dry bacterial bran (DBB), whereas, WS, GB, and PS showed 2.7 U, $1.2 \mathrm{U}$, and 1.5 $\mathrm{U}$ of enzyme per gram DBB respectively. The universal suitability of wheat bran may be due to the fact that it contains sufficient nutrients and is able to remain loose even in moist conditions, thereby providing a large surface area $[10,32]$.

We have investigated the effect of different moistening agents on the production of carrageenase by $P$. aeruginosa by SSF. Among the four different moistening agents tested, MMS-IV showed maximum production of carrageenase (5.6 U/g DBB) as it is compared to that of other moistening agents which showed activity ranging between 3.4 to $3.8 \mathrm{U} / \mathrm{g}$ DBB (Table 1).

It is apparent from Figure 2 that the moisture content happens to be a critical parameter under successful SSF for the production of high levels of enzymes. It is evident from the figure that a maximum enzyme level of $6.4 \mathrm{U} / \mathrm{g}$ DBB was achieved under SSF at an initial ratio of WB to MMS IV medium of 1:2.5 (w/v). It was observed that the production of enzyme levels under SSF increased with the increase in the levels of moistening agent to WB until it reached 1(WB): 2.5 (MMS IV), however, a further increase in the levels of moistening agent to 3 showed a drastic decrease in the enzyme production (3.2 U/g DBB). Generally bacteria require high water activity for their growth and metabolism. The water impregnated solid-substrate leaches the nutrients into the absorbed and surrounding water. The nutrient enriched necessary moisture also enhanced the possible oxygen transfer thus, supports the growth of the bacterium and enzyme production [33]. A low level of moisture fails to impregnate and swell the solid substrate, which limits the nutrient enrichment of MMS and also decreases water activity. The sub-optimal water activity and nutrient limitation limits the bacterial growth and metabolism which in turn decrease the production of enzyme $[32,34,35]$. However, a higher than optimum moisture level promotes stickiness (gummy) in the texture of bran which lead to the change in particle structure causing decrease of porosity which, may limit the oxygen transfer and thus the growth and the metabolism of bacterium $[5,36]$.

The influence of incubation temperature on the production of carrageenase is growth associated. The increase in the incubation temperature from $30^{\circ} \mathrm{C}$ to $37^{\circ} \mathrm{C}$ showed the increase in the production of enzyme levels from $4 \mathrm{U} / g \mathrm{DBB}$ to $6.4 \mathrm{U} / \mathrm{g} \mathrm{DBB}$ respectively, however, a further increase in the incubation temperature to $45^{\circ} \mathrm{C}$ and $50^{\circ} \mathrm{C}$ caused the decrease in the enzyme production to around 3 $\mathrm{U} / \mathrm{g}$ DBB (Figure 3). The growth and the metabolism of the bacterium are linked to the optimal temperature under standard SSF conditions [8]. In this case the bacterium produced maximum enzyme at $37^{\circ} \mathrm{C}$ and the production decreased at $45^{\circ} \mathrm{C}$ and $50^{\circ} \mathrm{C}$, this may be due to the low biomass production and decrease of metabolic activity at high temperature. It has also been reported that the metabolic heat generated during microbial cultivation in SSF exerts harmful effects on the microbial activity [37] and thus the initial set temperature is vital.

The effect of inoculums size on the production of carrageenase by $P$. aeruginosa under SSF evidences that an optimal inoculum size of $10 \%$ produced maximum enzyme levels of $6.4 \mathrm{U} / \mathrm{g}$ DBB (Figure 4). The SSF system (WB:MMS IV,1:2.5) showed a gradual increase in the enzyme production as the inoculums size was increased from $5 \%$

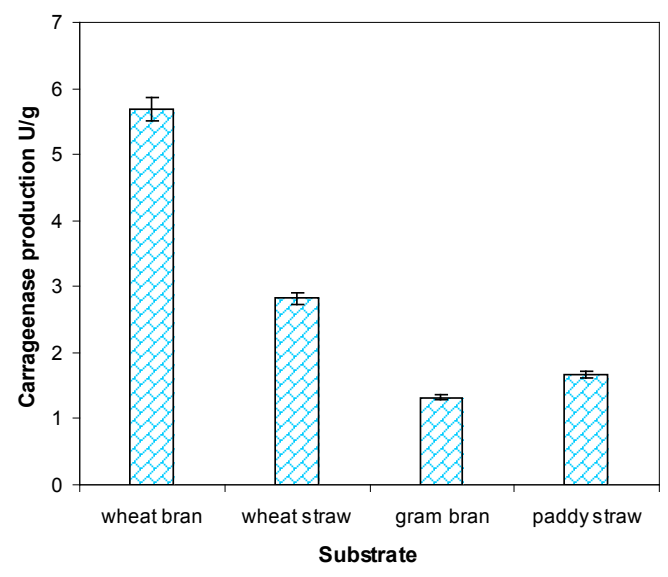

Figure 1: Carrageenase production by Pseudomonas aeruginosa ZSL-2 on various solid substrates by SSF. Culture conditions: Moistening media MMSIV with moisture content, $1: 2$; incubation temperature, $37^{\circ} \mathrm{C}$; Inoculum size, $10 \%(\mathrm{v} / \mathrm{w})$; fermentation period: $48 \mathrm{~h}$.Values are means $\pm \mathrm{SD}$ of triplicate determinations. 


\begin{tabular}{|c|c|}
\hline Moistening agent & Enzyme production (U/g DBB) \\
\hline Moistening agent I & $3.42 \pm 0.1026$ \\
\hline Moistening agent II & $3.81 \pm 0.1143$ \\
\hline Moistening agent III & $3.60 \pm 0.1080$ \\
\hline Moistening agent IV & $5.60 \pm 0.1208$ \\
\hline
\end{tabular}

${ }^{*}$ Refer the material and method section for the composition of the moistening agents

$\mathrm{DBB}=$ dry bacterial bran

Table 1: Carrageenase production by $P$. aeruginosa ZSL-2 under SSF using various moistening agents.

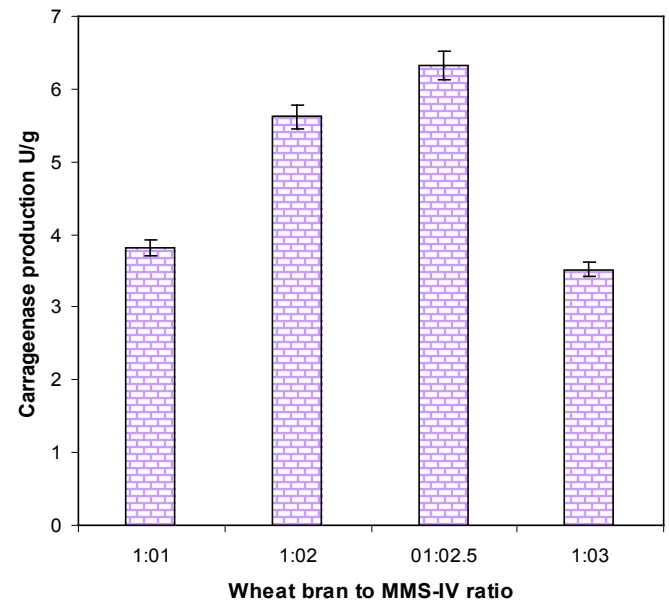

Figure 2: Effect of moisture level on carrageenase production in SSF. Culture conditions: MMS-IV; Incubation temperature, $37^{\circ} \mathrm{C}$; Inoculum size, $10 \%(\mathrm{v} / \mathrm{w})$ fermentation period, $48 \mathrm{~h}$. Values are means \pm SD of triplicate determinations.

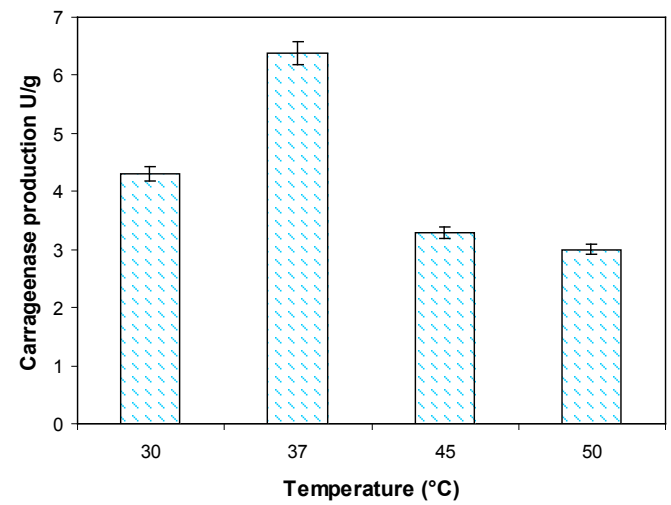

Figure 3: Effect of temperature on carrageenase production in SSF. Culture conditions: Wheat bran to moistening ratio, 1:2.5; Inoculum size, $10 \%(\mathrm{v} / \mathrm{w})$; fermentation period, $48 \mathrm{~h}$.

to $10 \%$ whereas, a sharp decrease in the level of enzyme production observed when the inoculums level is increased to $15 \%$. This may be due to the limiting nutrient levels available at higher inoculums size [8] in the water core of SSF system as the nutrient leaching is a gradual process and high initial bacterial population may have caused a vacuum for nutrients where in the bacterium may prefer maintenance rather than production of secondary enzyme.

In the SSF condition, the production of carrageenase by the bacterium increased with the increase in the incubation time and reached maximum at $48 \mathrm{~h}(6.5 \mathrm{U} / \mathrm{g} \mathrm{DBB})$ of incubation (Figure 5). A further increase in the incubation time resulted in the decreased levels of enzyme production under similar SSF conditions. A $4.2 \mathrm{U}$, $2.8 \mathrm{U}$ and $2.2 \mathrm{U}$ of carrageenase were produced by the system at 72 h, $92 \mathrm{~h}$ and $120 \mathrm{~h}$ respectively. Most of the reported studies employed a fermentation period of $48 \mathrm{~h}$ for bacteria and 5-9 days for fungus $[38,39]$. The incubation time is governed by characteristics of the organism and is based on growth rate and production $[40,41]$. The $P$. aeruginosa ZSL-2 also produced extracellular protease (data not shown) thus the decline in carrageenase levels after $72 \mathrm{~h}$ of incubation may be due to the hydrolysis of enzyme by extracellular proteases produced by same organism and also due to the lysis of bacteria. Our results on the decreased levels of carrageenase enzyme after prolonged incubation are in agreement with [42-44], where in authors reported the decline in protease activity upon prolonged incubation may be due to autolysis of the enzyme.

The orthogonal matrix method was obviously a bioprocess engineering design to simultaneously investigate precise levels of different parameters for bioprocess design. The orthogonal experimental design technique is a mathematical method that enables one to study the relationships among various factors $[27,30,45]$. The Latin square used to optimize the nutritional factors was L9 $\left(3^{4}\right)$ (Table 2), where L9 indicates a Latin square with nine combinations of variables and $\left(3^{4}\right)$ denotes four factors with three levels. Appropriately selecting the factor can improve the quality of the product, especially when at least two quality characteristics are to be simultaneously considered. The selection of the factor should account for the objectives of the study

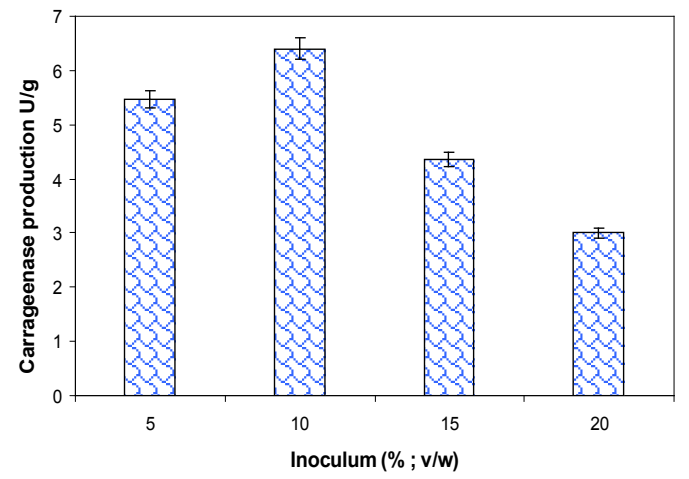

Figure 4: Effect of inoculum size on carrageenase production in SSF. Culture conditions: Wheat bran to moistening ratio, $1: 2.5$; Incubation temperature, $37^{\circ} \mathrm{C}$; fermentation period, $48 \mathrm{~h}$. Values are means \pm SD of triplicate determinations.

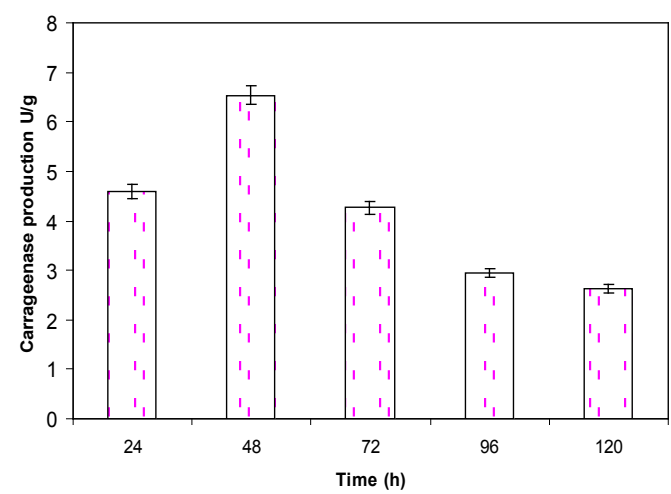

Figure 5: Effect of fermentation period on carrageenase production in SSF. Culture conditions: Wheat bran to moistening ratio, 1:2.5; Incubation temperature, $37^{\circ} \mathrm{C}$; Inoculum size, $10 \%(\mathrm{v} / \mathrm{w})$. Values are means $\pm \mathrm{SD}$ of triplicate determinations. 
and feasibility and ease of handling the optimization process [46]. In present study, four factors optimized were fermentation period, temperature, inoculums volume and substrate to moisture level. The three levels of the factors associated with the orthogonal matrix (Table 2) were set based on the concentration levels of each factor. The smallest orthogonal array was selected with minimum experiments that can assign all the design variables to their columns. The chosen four factors are assigned to columns A-D; that is, the columns are mutually orthogonal without overlapping.

The fermentation results of carrageenase production by the orthogonal matrix method are given in Table 3. The variance in factor/level combination shows the range over which the maximum carrageenase production changed with levels for each factor. The effects of these control factors on carrageenase production were determined by the analysis of variance technique to establish statistically significant factors. Intuitive analyses and statistical calculations based on historical data analysis are shown in Table 4. The data obtained from the orthogonal array method represents the response table for means (larger is better). The last two rows in the Table 3 document the delta values and ranks for the system. Rank and delta values help to assess which factors have the greatest effect on the response characteristic of

\begin{tabular}{|c|c|c|c|c|}
\hline Factors & $\begin{array}{c}\text { Temperature } \\
\mathbf{A}\left({ }^{\mathbf{C}} \mathbf{C}\right)\end{array}$ & $\begin{array}{c}\text { Time } \\
\mathbf{B}(\mathbf{h})\end{array}$ & $\begin{array}{c}\text { Inoculum } \\
\mathbf{C}(\mathbf{\%})\end{array}$ & $\begin{array}{c}\text { Moisture } \\
\mathbf{D}(\mathbf{w} / \mathbf{v})\end{array}$ \\
\hline level 1 & 30 & 24 & 5 & $1: 2$ \\
\hline level 2 & 37 & 48 & 10 & $1: 2.5$ \\
\hline level 3 & 45 & 72 & 15 & $1: 3$ \\
\hline
\end{tabular}

Each factor is denoted by symbols A, B, C, and D.

The optimum level for each factor is obtained by concentration experiment of each factor.

Table 2: Factors and their levels employed in the $L_{9}\left(3^{4}\right)$ Orthogonal Array of Taguchi Experimental Design for Carrageenase production by $P$. aeruginosa ZSL2 in SSF.

\begin{tabular}{|c|c|c|c|c|c|}
\hline S.No. & A & B & C & D & $\begin{array}{c}\text { Carrageenase } \\
\text { activity (U/g) }\end{array}$ \\
\hline 1 & 1 & 1 & 1 & 1 & $1.17 \pm 0.0117$ \\
\hline 2 & 1 & 2 & 2 & 2 & $2.16 \pm 0.0216$ \\
\hline 3 & 1 & 3 & 3 & 3 & $0.96 \pm 0.0096$ \\
\hline 4 & 2 & 1 & 2 & 3 & $6.24 \pm 0.0624$ \\
\hline 5 & 2 & 2 & 3 & 1 & $7.02 \pm 0.0702$ \\
\hline 6 & 2 & 3 & 1 & 2 & $5.88 \pm 0.0588$ \\
\hline 7 & 3 & 1 & 3 & 2 & $1.14 \pm 0.0114$ \\
\hline 8 & 3 & 2 & 1 & 3 & $1.44 \pm 0.0144$ \\
\hline 9 & 3 & 3 & 2 & 1 & $0.96 \pm 0.0096$ \\
\hline${ }^{a} K 1$ & 4.29 & 8.55 & 8.49 & 9.15 & \\
\hline$K 2$ & 19.14 & 10.62 & 9.36 & 9.18 & \\
\hline$K 3$ & 3.54 & 7.8 & 9.12 & 8.64 & \\
\hline${ }^{b} k 1$ & 1.43 & 2.85 & 2.83 & 3.05 & \\
\hline$k 2$ & 6.38 & 3.54 & 3.12 & 3.06 & \\
\hline$k 3$ & 1.18 & 2.6 & 3.04 & 2.88 & \\
\hline${ }^{c} \Delta$ & 5.2 & 0.94 & 0.29 & 0.18 & \\
\hline$R$ & 1 & 2 & 3 & 4 & \\
\hline Optimization & $\mathrm{A}_{2}$ & $\mathrm{~B}_{2}$ & $\mathrm{C}_{2}$ & $\mathrm{D}_{2}$ & \\
\hline
\end{tabular}

The assignments of column A, B, C, and D were performed by orthogonal array consisted of nine experiments corresponding to the nine rows and four columns.

${ }^{a} k=\sum k$ of all experiment at the same factor level.

${ }^{\mathrm{b}}$ Average of $k$

${ }^{\mathrm{c}} \Delta=\max \left\{\right.$ average of $\left.k_{i}\right\}$ - $\min \left\{\right.$ average of $\left.k_{i}\right\}$.

Values are mean of triple determinations with standard deviation ( \pm ).

Table 3: $L_{g}\left(3^{4}\right)$ Orthogonal Array of Taguchi Experimental Design and corresponding Carrageenase production by $P$. aeruginosa ZSL-2 under SSF.

\begin{tabular}{|l|l|l|l|l|l|l|}
\hline & $\begin{array}{l}\text { Sum of } \\
\text { squares }\end{array}$ & df & $\begin{array}{l}\text { Mean of } \\
\text { square }\end{array}$ & F value & Critical value & Significance \\
\hline Temperature & 17.201 & 2 & 8.6005 & 3.887276 & & \\
\hline Time & 0.474 & 2 & 0.237 & 0.10712 & & \\
\hline lonoculum & 0.0044 & 2 & 0.0022 & 0.000994 & & \\
\hline Moisture & 0.0204 & 2 & 0.0102 & 0.00461 & & \\
\hline error & 17.6998 & 8 & 2.212475 & & & \\
\hline
\end{tabular}

* Significant terms.

Table 4. ANOVA of Orthogonal Array test data

interest. Delta measures the size of the effect by taking the difference between the highest and the lowest characteristic average for a factor. The higher the delta value, greater is the effect of that component on carrageenase production. Rank, orders the factors from the greatest effect (based on the delta values) to the least effect on the response characteristic. According to the magnitude of order of delta, the order of effect of these factors on carrageenase production was temperature $>$ time $>$ inoculum $>$ moisture. The optimum culture conditions obtained from the statistical analysis were A2B2C2D2. The optimal culture conditions for carrgeenase production were calculated to be temperature $37^{\circ} \mathrm{C}$, incubation time $48 \mathrm{~h}$, inoculums size $10 \%$ and $\mathrm{WB}$ to moistening agent $(1: 2.5, \mathrm{w} / \mathrm{v})$. The results of ANOVA (Table 4) revealed that the temperature has significant influence on carrgeenase production by the bacterium under SSF conditions. Further, based on the optimal culture conditions revealed by the statistical approach of OATS, the production of carrageenase levels by the SSF system was performed and validated at 7.44 $\pm 0.37 \mathrm{U} / \mathrm{g} \mathrm{DBB}$, which is higher than that of the basal culture conditions.

The synergistic effects on carrageenase production can be examined in medium optimized with the optimal condition of temperature, inoculums size and substrate to moisture level. In addition, the orthogonal matrix can simultaneously investigate many more factors, for instance central composite design, and thus facilitates economical benefit, experimental convenience, while being competitively rapid and precise. It means that the orthogonal matrix method is a useful tool for optimizing the determination conditions of carrageenase production in a solid state fermentation process. Some researchers have successfully applied it to optimization of culture media for the production of primary and secondary metabolites in fermentation processes $[27,41,45,47,48]$.

The effect of additional carbon sources on carrageenase production by the bacterium in SSF was tested in MMS-IV medium supplemented with $1 \%$ carbohydrate (Figure 6). The supplementation of carrageenan (1\%) in SSF (WB moistened with MMS IV) showed $6.94 \mathrm{U}$ of carrageenase per gram DBB as compared to control (6.48 U/g DBB). The addition of different carbon sources however, did not influence significantly on the production of enzyme. Moreover, glucose, which completely repressed carrageenase production in submerged cultivation (data not shown), was tolerated in SSF up to $2 \%$ without lowering the enzyme titre, while beyond this level, the production was found to be declined (Figure 7). These results revealed that wheat bran itself acts as a source of carbon, nitrogen and minerals as well as growth factors.

\section{Conclusion}

Using the one factor at a time method and orthogonal matrix method, it was possible to determine optimal conditions to obtain high yield of carrageenase. This is the first report on the production of 


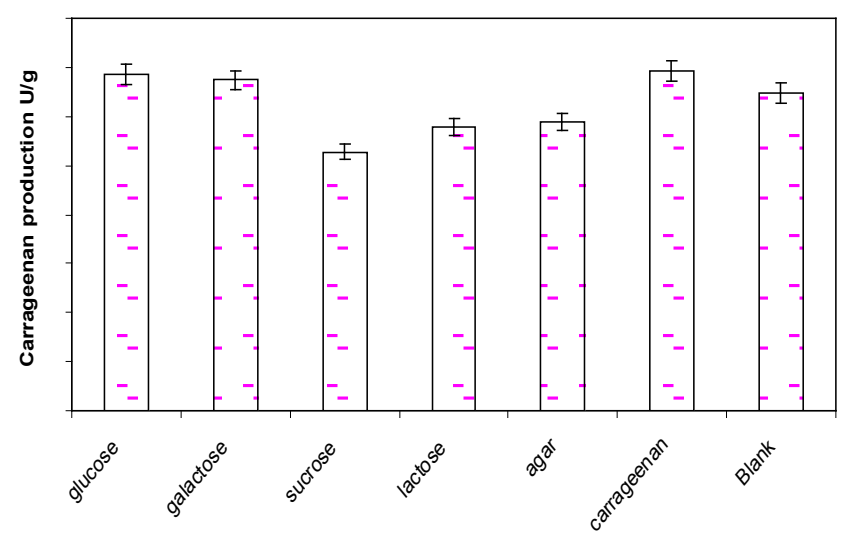

carbon source $(1 \%)$

Figure 6: Effect of additional carbon sources on carrageenase production in SSF (Blank: - mineral salt medium without any additional carbon sources). Values are means \pm SD of triplicate determinations.

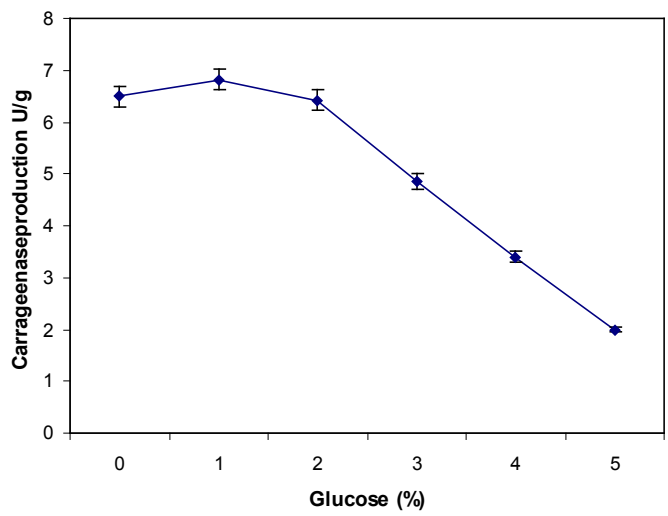

Figure 7: Effect of glucose on carrageenase production in SSF. Culture conditions: Moisture content, 1:2.5; Incubation temperature, $37^{\circ} \mathrm{C}$; Inoculum size, $10 \%(\mathrm{v} / \mathrm{w})$; fermentation period, $48 \mathrm{~h}$. Values are means $\pm \mathrm{SD}$ of triplicate determinations.

carrageenase by $P$. aeruginosa using SSF process. SSF is an economically viable process as the substrate used is inexpensive. The findings suggest that there is possibility of microbial technology for the production of carrageenase by this bacterium under SSF bioprocess conditions for its application in industry. The bacterium grows luxuriantly and produces high levels of carrageenase on wheat bran under SSF without demanding for any additional carbon source thus cutting down the production cost.

\section{Acknowledgements}

This work was supported in part by research grant from Department of Science and Technology (DST), New Delhi, India (Project No. 100/IFD/5186/2007-2008 dated 6/11/2007). Ziayoddin $M$ is grateful to UGC for Junior Research Fellowship (MANF JRF (No.F.40-49(M)/2009(SA-III/MANF) dated 08 Jan 2011) and also to Gulbarga University, Gulbarga for laboratory facility.

\section{References}

1. Pandey A (1992) Recent process developments in solid-state fermentation. Process Biochem 27: 109-117.

2. Nigam P, Singh D (1995) Enzyme and microbial systems involved in starch processing. Enzyme Microb Technol 17: 770-778.

3. Chadha BS, Singh S, Vohra G, Saini HS (1997) Shake culture studies for the production of amylases by Thermomyces lanuginosus. Acta Microbiol Immunol Hung 44: 181-185.
4. Pandey A, Nigam P, Soccol CR, Soccol VT, Singh D, et al. (2000) Advances in microbial amylases. Biotechnol Appl Biochem 31: 135-152.

5. Lonsane BK, Ghildyal NP, Budiatman S, Ramakrishna SV (1985) Engineering aspects of solid state fermentation. Enzyme Microb Technol 7: 258-265.

6. Pandey A, Soccol CR, Mitchell D (2000) New developments in solid state fermentation: I-bioprocesses and products. Process Biochem 35: 1153-1169.

7. Pandey A, Soccol CR, Rodriguez-Leon JA, Nigam P (2001) Solid-State Fermentation in Biotechnology: Fundamentals and Applications. Asiatech Publishers Inc., New Delhi, India 22.

8. Gangadharan D, Sivaramakrishnan S, Nampoothiri KM, Ashok Pandey (2006) Solid Culturing of Bacillus amyloliquefaciens for Alpha Amylase Production. Food Technol Biotechnol 44: 269-274

9. Arima K (1964) Microbial enzyme production. In: Global Impacts of Applied Microbiology (Starr MP Ed.), Wiley, New York, 221-294

10. Satyanarayana T (1994) Production of bacterial extracellular enzymes by solid state fermentation. In: Solid State Fermentation (Pandey A Edtn), Wiley Eastern Ltd. New Delhi, India, 122-129.

11. Babu KR, Satyanarayana T (1995) a-Amylase production by thermophilic Bacillus coagulans in solid state fermentation. Process Biochem 30: 305-309.

12. Raimbault M, Alazard D (1980) Culture method to study fungal growth in solid fermentation. Appl Microbiol Biotechnol 9: 199-209.

13. NHideki N, Yosuki K, Toshima Y, Sumalee P, Ryuzo U, et al. (1982) Growth and enzyme production in a solid-state culture of Aspergillus oryzae. Journal of Fermentation Technology 60: 311-319.

14. Qadeer MA, Anjum JI, Akhtar R (1980) Biosynthesis of enzymes by solid state fermentation. Part II. Production of a-amylase by Bacillus subtilis. Pak J Sci Ind Res 23: 25-29.

15. Germano S, Pandey A, Osaku CA, Rocha SN, Soccol CR (2003) Characterization and stability of protease from Penicillum sp. produced by solid-state fermentation. Enzyme Microb Technol 32: 246-251.

16. Krishna C, Chandrasekaran M (1996) Banana waste as substrate for a-amylase production by Bacillus subtilis (CBTK 106) under solid state fermentation. App Microbiol Biotechnol 46: 106-111.

17. Kashyap DR, Soni SK, Tewari R (2003) Enhanced production of pectinase by Bacillus sp. DT7 using solid state fermentation. Bioresour Technol 88: 251-254.

18. Ostgaard K, Wangen BF, Knutsen SH, Aasen IM (1993) Large-scale production and purification of $\mathrm{K}$-carrageenase from Pseudomonas carrageenovora fo applications in seaweed biotechnology. Enzyme Microb Technol 15: 326-333.

19. Dyrset N, Lystad KQ, Levine DW (1997) Development of a fermentation process for production of a $\mathrm{K}$-carrageenase from Pseudomonas carrageenovora. Enzyme Microb Technol 20: 418-423.

20. Michel G, Chantalat L, Duee E, Barbeyron T, Henrissat B, et al. (2001) The K- carrageenase of $P$. carrageenovora features a tunnel-shaped active site: a novel insight in the evolution of Clan-B glycoside hydrolases. Structure 9 . 513-525.

21. Potin P, Sanseau A, Le Gall Y, Rochas C, Kloareg B (1991) Purification and characterization of a new kappa-carrageenase from a marine Cytophaga-like bacterium. Eur J Biochem 201: 241-247.

22. Barbeyron T, Gerard A, Potin P, Henrissat B, Kloareg B (1998) The kappacarrageenase of the marine bacterium Cytophaga drobachiensis. Structura and phylogenetic relationships within family-16 glycoside hydrolases. Mol Biol Evol 15: 528-537.

23. Barbeyron T, Henrissat B, Kloareg B (1994) The gene encoding the kappacarrageenase of Alteromonas carrageenovora is related to beta-1,3-1,4 glucanases. Gene 139: 105-109.

24. Potin P, Richard C, Barbeyron T, Henrissat B, Gey C, et al. (1995) Processing and hydrolytic mechanism of the cgkA-encoded kappa-carrageenase of Alteromonas carrageenovora. Eur J Biochem 228: 971-975.

25. Araki T, Higashimoto Y, Morishita T (1999) Purification and characterization of $\mathrm{k}$-carrageenase from a marine bacterium, Vibrio sp. CA-1004. Fish Sci 65 937-942.

26. Barbeyron T, L'Haridon S, Corre E, Kloareg B, Potin P (2001) Zobellia galactanovorans gen. nov., sp. nov., a marine species of Flavobacteriaceae 
Citation: Ziayoddin M, Shinde M, Lalitha J (2012) Orthogonal Array Approach for Optimization of Carrageenase Production by Solid State Fermentation of Pseudomonas aeruginosa ZSL-2. J Microb Biochem Technol 4: 096-095. doi:10.4172/1948-5948.1000078

isolated from a red alga, and classification of [Cytophaga] uliginosa (ZoBell and Upham 1944) Reichenbach 1989 as Zobellia uliginosa gen. nov., comb. nov. Int J Syst Evol Microbiol 51: 985-997.

27. Xu CP, Kim SW, Hwang HJ, Choi JW, Yun JW (2003) Optimization of submerged culture conditions for mycelial growth and exo-biopolymer production by Paecilomyces tenuipes C240. Process Biochem 38: 1025-1030.

28. Ziayoddin M, Manohar S, Lalitha J (2010) Isolation of agar degrading bacterium Pseudomonas aeruginosa ZSL-2 from a marine sample. The Bioscan 5: 279 283.

29. Dygert S, Li LH, Florida D, Thoma JA (1965) Determination of reducing sugar with improved precision. Anal Biochem 13: 367-374.

30. Li Y, Chen J, Lun SY, Rui XS (2001) Efficient pyruvate production by a multivitamin auxotroph of Torulopsis glabrata: key role and optimization of vitamin levels. Appl Microbiol Biotechnol 55: 680-685.

31. Di X, Chan K, Leung HW, Huie CW (2003) Fingerprint profiling of acid hydrolyzates of polysaccharides extracted from the fruiting bodies and spores of Lingzhi by high-performance thin-layer chromatography. J Chromatogr A 1018: 85-95.

32. Feniksova RV, Tikhomirova AS, Rakheleeva EE (1960) [Conditions of amylase and proteinase formation in a surface culture of Bacillus subtilis]. Mikrobiologiia 29: $745-748$

33. Raghavarao KSMS, Ranganathan TV, Karanth NG (2003) Some engineering aspects of solid-state fermentation. Biochem Eng J 13: 127-135.

34. Gervais $P$, Molin P (2003) The role of water in solid-state fermentation. Biochem Eng J 13: 85-101.

35. Ramesh MV, Lonsane BK (1990) Critical importance of moisture content of the medium in alpha amylase production by Bacillus licheniformis M27 in a solid state fermentation medium. Appl Microbiol Biotechnol 33: 501-505.

36. Sodhi HK, Sharma K, Gupta JK, Soni SK (2005) Production of a thermostable $\alpha$-amylase from Bacillus $s p$. PS-7 by solid state fermentation and its synergistic use in the hydrolysis of malt starch for alcohol production. Process Biochem 40: $525-534$

37. Pandey A (1990) Improvement in solid-state fermentation for glucoamylase production. Biological Wastes 34: 11-19.
38. Aikat K, Bhattacharyya BC (2000) Protease extraction in solid state fermentation of wheat bran by a local strain of Rhizopus oryzae and growth studies by the soft gel technique. Process Biochem 35: 907-914.

39. Puri S, Beg QK, Gupta R (2002) Optimization of alkaline protease production from Bacillus sp. by response surface methodology. Curr Microbiol 44: 286290

40. Park YK, Rivera BC (1982) Alcohol production from various enzymes-converted starches with or without cooking. Biotechnol Bioeng 24: 495-500.

41. Baysal Z, Uyar F, Aytekin C (2003) Solid state fermentation for production of a-amylase by a thermotolerant Bacillus subtilis from hot-spring water. Process Biochem 38: 1665-1668.

42. Nilegaonkar SS, Zambare VP, Kanekar PP, Dhakephalkar PK, Sarnaik SS (2007) Production and partial characterization of dehairing protease from Bacillus cereus MCM B-326. Bioresour Technol 98: 1238-1245.

43. Shivakumar S (2012) Co-production of alkaline protease and amylase of Bacillus $\mathrm{sp} \mathrm{Y}$ in solid state cultivations. Research Journal of Biotechnology 7 : 32-37.

44. Kunamneni A, Permaul K, Singh S (2005) Amylase production in solid state fermentation by the thermophilic fungus Thermomyces lanuginosus. J Biosc Bioeng 100: 168-171.

45. Escamilla EM, Dendooven L, Magaña IP, Parra R, De la Torre M (2000) Optimization of gibberellic acid production by immobilized Gibberella fujikuro mycelium in fluidized bioreactors. J Biotechnol 76: 147-155.

46. Houng JY, Hsu HF, Liu YH, Wu JY (2003) Applying the Taguchi robust design to the optimization of the asymmetric reduction of ethyl 4-chloro acetoacetate by bakers' yeast. J Biotechnol 100: 239-250.

47. Lee MT, Chen WC, Chou CC (1997) Medium improvement by orthogona array design for cholesterol oxidase production by Rhodococcus equi no. 23 Process Biochem 32: 697-703.

48. Fan Y, Wang Y, Qian PY, Gu JD (2004) Optimization of phthalic acid batch biodegradation and the use of modified Richards model for modelling degradation. Int Biodeterior Biodegradation 53: 57-63. 